\title{
Proje Tabanlı Öğrenme Kapsamında Gerçekleştirilen Ders Dışı Egzersiz Çalışmalarına İliş̧kin Öğrenci Görüşleri
}

\section{Students Opinion about Extra Curricular Exercises Performed within the Scope of Project Based Learning}

\author{
Şahin İdin, Dr. Mustafa Necati Ortaokulu, sahinidin@hotmail.com \\ Pınar Özdemir Şimșek, Yrd. Doç. Dr. Hacettepe Üniversitesi, Eğitim Fakültesi, pozdem@hacettepe.edu.tr
}

\begin{abstract}
öZ. Bu araştırma ile ilköğretim ikinci kademede öğrenim görmekte olan öğrencilerin, Fen ve Teknoloji dersi bağlamında ders dışı egzersiz kapsamında yaptıkları proje çalışmalarına ilişkin görüșlerinin belirlenmesi amaçlanmıștır. Çalışma grubunu, Ankara'daki bir ilköğretim okulunda ikinci kademede öğrenim gören yedi öğrenci oluşturmaktadır. Bu araştırmada nitel araştırma yöntemi benimsenmiştir. Açık uçlu sorulardan oluşturulmuş bir görüşme formu ile proje çalıșmalarına katılan beș öğrenci ile yarı yapılandırılmıș görüșmeler yapılmıștır. Çalıșma grubunu oluşturan yedi öğrenci çalışma sürecinde gözlemlenmiştir. Öğrenciler proje çalışmalarının Fen ve Teknoloji ders başarılarına olumlu katkılar getirdiğini, diğer dersleri sevmeye karşı olumlu tutumlar geliştirdiğini, diğer disiplinler ile ilişki kurmalarını sağladıklarını, belirtmişlerdir. Fen ve Teknoloji dersi kapsamında ders dışı egzersiz çalışmaları olarak yürütülen bu çalışmaların ders içinde de etkin olarak kullanılabileceği öneriler arasında yer almaktadır.
\end{abstract}

Anahtar Kelimeler: Fen ve Teknoloji, Proje Tabanlı Öğrenme, Nitel Araştırma

\begin{abstract}
The purpose of this relevant research was to determine the perceptions that related to effects of the projects carried out by the secondary school students in their extracurricular exercises on their Science and Technology lesson's achievement. The sample of the study consisted of seven students attending in a secondary school in Ankara. In this research, the qualitative research techniques were used to collect data. The semi-structured interviews were carried out with 5 students who participated in the project study. Furthermore, 7 students who constituted the research had been observed. Regarding the research study, they stated that the project study brought positive contribution on their Science and Technology lesson; it made them develop positive attitudes and provided them to make the connection with the other disciplines. It was among the other suggestions that these kinds of studies designed as an extracurricular exercises within the concept of the Science and Technology lesson and can also be used during the class activities effectively.

Keywords: Science and Technology, Project Based Learning, Qualitative Methods
\end{abstract}

\section{SUMMARY}

Purpose and Significance: The general aim of this research was to examine the effects of the extracurricular projects studies on the students' Science and Technology lesson and to get the perceptions of the students related to that issue. This research was mainly based on whether the project studies had any effects on the students' interest for the Science and Technology lesson, their achievements for the lessons and the change of their perspective for the other interdisciplinary lessons.

Methodology: In this research, among the general research techniques, the qualitative method was used. It was a case study in terms of design pattern. The interviews and the observation were the techniques that were used as the qualitative techniques. The interview form was used to observe the progress that was made by the students during the process. The interview forms consisted of mainly 9 open ended questions. For this purpose, interview form was constructed which was prepared in relation to the sub-problems of the study and it consisted of open ended questions with alternative questions and probes. Based on the voluntariness of the students interviews was carried out with the 5 students participating in the project. The interview data was 
subjected to descriptive analysis and the observation data has been subjected to content analysis. As in the all qualitative research, the necessary arrangements were made for the internal and external validity of the study in this research.

Results: At the end of the study, it has been determined that materials were not complex products. The students claimed that the materials were easily found, simple structured and practical products. They also told that they did not need complicated materials for their studies. The students also stated that they could easily use the abilities that they gained in their Science and Technology lessons, in their curricular activities and in their daily life. At the end of the project study, based on data, it could be stated that the achievement of the students has increased.

Discussion and Conclusion: It was recognized that the study made by the students who participated in the project study were highly consisted of the same unit extent. To make the students integrate to the other disciplines successively, it can be recommended that to prepare projects, the students may take their selections from the other topics in units. Considering the fact that there was an increase on the achievement of the students with the means of Science and Technology lesson, it may be stated that more students may participate in these studies.

\section{GíRiş}

Değişen ve gelişen dünya koşullarında ülkeler refah seviyelerini artırmak ve ileri kalkınmış topluma sahip olabilmek için eğitim sistemlerinde değişikliklere gidebilmektedirler. Çağın gereklerine uygun öğrenme ve öğretme yaklaşımları eğitim müfredatlarında kullanılmaktadır. Bu yenilikçi yaklaşımlardan biri de Proje Tabanlı Öğrenme (PTÖ) yaklaşımı ve bu kapsamda gerçekleștirilen proje çalıșmalarıdır. Zorbaz ve Çeçen (2009); Proje Tabanlı Öğrenme kavramının ülkemizde yapılan araștırmalarda, Proje Tabanlı Öğrenme, Projeye Dayalı Öğretim, Proje Tabanlı Öğrenme Yaklaşımı, Proje Tabanlı Öğrenme Modeli, Proje Tabanlı Öğrenme Yöntemi, Proje Tabanlı Öğrenme Yaklaşımı, Proje Yöntemi ve Proje Çalışması gibi farklı isimlerle adlandırıldıklarını belirlemişlerdir.

Projeler, öğrencilerin genellikle somut bir ürüne ulaşmak için tek başlarına ya da küçük gruplar halinde bir görev dâhilinde uzun bir süre bireysel veya birlikte çalışmaları olarak tanımlanmaktadır. (Saban, 2000). Katz (2000)'a göre hayatı destekleyecek nitelikte, ilgi alanı geniş bir konu alanı hakkında derin araştırma yapmaya proje çalışması, ortaya konan ürüne proje ve bu süreçte yer alan yaklaşıma da Proje Tabanlı Öğrenme yaklaşımı olarak tanımlamıştır (akt. Yurttepe, 2007). Erdem ve Akkoyunlu (2002), Proje Tabanlı Öğrenme (PTÖ) yaklaşımında üç ana kavramdan bahsetmektedirler. Bu kavramlardan biri olan "öğrenme" kavramı ile dikkat öğretenden ziyade öğrenene çekilmektedir. Bir diğer kavram olan "tabanlı" sözcüğü ile süreç yönelimli yapılanmaya işaret edilerek projenin bir hedef olmadığı vurgulanmaktadır. "Proje" kavramı ile de, öğrenmenin ürün değil süreç boyutuna dikkat çekilmekte, belli bir amaca dönük ilişkisel öğrenme vurgulanmaktadır. Colley (2008), PTÖ’yü öğrencilerin yaşadıkları toplumlarda ya da yaşantılarında görülen problemleri bilimsel bir yol eşliğinde çözmeleri ve bunu raporlandırmalarına dayalı bir yöntem olarak tanımlamaktadır (akt. Aydın, 2011).

Proje çalışmaları tek başına bir konu değildir. Matematikte olduğu gibi, matematiksel görüş açısını ve kavramları öğrencilere temel açısından kazandırmaktır. Proje çalışması eğitim programında yer alan tüm konuları tamamlayıcı bir öge olarak kabul edilmelidir (Korkmaz ve Kaptan, 2002). Proje çalışmalarına katılan öğrencilerde bir takım değişikliklerin süreç içerisinde oluşması beklenmektedir. PTÖ yaklaşımı ile projenin odaklandığı konuları öğrenme, bireysel ve grup içerisinde çalışma stratejilerini bilme, öğrencinin üretken ve yaratıcı olmasını sağlama, kendine güvenen ve saygın kişilik oluşturma, araştırma ve üst düzey düşünme becerisi geliştirme gibi özellikleri sağlamaktadır. (Erdem, 2002). PTÖ yaklaşımının yapısı ve içeriği ile Fen ve Teknoloji dersinin öğretiminde de kullanılmaktadır. Milli Eğitim Bakanlığı (MEB), Fen ve Teknoloji Dersi Öğretim Programı'nda dersin işlenişinde kullanılması önerilen yeni yaklaşımlardan biri olarak vurgulanmaktadır (MEB, 2005).

Fen ve Teknoloji öğretiminin en önemli öğelerinden birisi de "fen ve teknoloji okuryazarlığı" kavramıdır (Akcay ve Akcay, 2015). Fen ve Teknoloji okuryazarlığı, genel bir tanım olarak; bireylerin araştırma sorgulama, eleştirel düşünme, problem çözme ve karar verme becerileri 
geliştirmeleri, yaşam boyu öğrenen bireyler olmaları, çevreleri ve dünya hakkındaki merak duygusunu sürdürmeleri için gerekli olan fenle ilgili beceri, tutum, değer, anlayış ve bilgilerin bir bileşimidir (MEB, 2005). Girgin (2003), yaptığı araştırmada, proje çalışmalarının öğrencilerin derslerine olan motivasyonlarını artırarak öğrenmelerini daha kalıcı kıldığını ortaya koymuştur. MEB (2005), Fen ve Teknoloji Dersi Öğretim Programı'nda vurgulandığı gibi fen okuryazarı bireyler yetiştirmek, programın temel vizyonu olarak görülmektedir. Bununla birlikte fen okuryazarı bireyler; araştıran, sorgulayan, merak eden, üreten, günlük yaşam ile teoriyi bütünleştirebilen özelliklere sahip bireyler olarak görülmektedir. Bu nedenle öğrencilerin özellikle dersteki kazanmış olduğu bilgi ve becerilerin günlük hayat ile ilişkilendirilmesi önemli yer tutmaktadır. Proje tabanlı öğrenme yöntemi bilgi ve becerilerin günlük hayat ile ilișkilendirilmesine yarar sağladığı söylenebilir. MEB (2015), aldığı karar doğrultusunda Fen ve Teknoloji Dersi Öğretim programında değişikliklere gitmiştir. Dersin adı "Fen Bilimleri" olarak değiştirilmiştir. Bunun yanında dersin işlenmesinde genel olarak Araştırıcı-Sorgulayıcı Öğrenme Yaklaşımı benimsenmiştir. Dersin öğretiminde; öğrencinin aktif ve öğretmenin rehber rolü olmasını belirterek bunu uygun öğrenme ortamlarının olușturulmasını temel almaktadır. Bu bağlamda bu öğrenme ortamlarından biri de Proje Tabanlı Öğrenme ortamları olarak belirlenmiștir. Ancak hem 2004 Fen ve Teknoloji Dersi Öğretim Programında hem de 2013 Fen Bilimleri Dersi Öğretim Programında Proje Tabanlı Öğrenmenin uygulanış biçimi, planı, hangi süreçlerde uygulanabileceği ile ilgili bir bilgi ve ders plana yer verilmemiştir. Yüzeysel olarak Fen Bilimleri derslerinde PTÖ'nün uygulanabileceği belirtilmiştir. Proje Tabanlı Öğrenme Yaklaşımının özelliklerinin Fen ve Teknoloji Dersi Öğretim Programının vizyonunda yer alan fen okuryazarı bireylerin yetiştirilmesine yönelik amaçlarla paralellik taşıdığı görülmektedir (MEB, 2005). Bu açılardan bakıldığında, PTÖ yaklaşımının Fen ve Teknoloji Dersi Öğretim Programında belirtilen vizyon, tutum ve değerler ve yaşam becerilerinin kazanılmasında etkili bir yöntem olabileceği söylenebilir. Fen ve Teknoloji dersinin öğretiminde dersin amaçları ile öğretim programı arasında ilişki olması açısından proje tabanlı öğrenme yaklaşımı önemli bir yere sahiptir. Sayılan bu özellikler PTÖ'nin öğrenme açısından öğrencilere sunduğu avantaj olarak belirtilebilir. Belirtilen nitelikler PTÖ ile birlikte süreç boyunca etkili biçimde kullanıldığında öğrencilerin fen ve teknoloji okuryazarı bireyler olmalarına yardımcı olunabilir.

Bununla birlikte MEB, 2005-2014 yılları arasında ülke genelinde Bu Benim Eserim (BBE) adlı proje çalışmasını yapmıştır. BBE kapsamında üretilen projeler, PTÖ yaklaşımına uyularak gerçekleştirilen çalışmaların ürünleridir. BBE, 2004-2015 yılları arasında teşvik amacı ile gerçekleștirilmiş bir proje çalışmasıdır. Öğrencilerin araştıran, sorgulayan ve merak eden bireyler olarak yetişmelerine yönelik geliştirilen bu proje çalışması MEB'in aldığı karar doğrultusunda 2015 yılında ulusal bir yarışmaya dönüştürülmüştür. Bu kapsamda ilköğretim okullarının 6-7 ve 8. Sınıf öğrencileri Fen ve Teknoloji Dersi kapsamında projeler sunabilmekteydiler. Ancak MEB proje çalışmaları kapsamında egzersiz programı açan öğretmenlere yönelik ilgili çalışmaların süreçlerinde neler yapılması gerektiği ile ilgili bilimsel bir alt yapı sunmamaktadır. İl ve İlçe Milli Eğitim Müdürlükleri bünyesinde ders öğretmenlerine BBE'yi tanıtıcı kısa bilgilendirme toplantıları ve seminerler verilmektedir (MEB, 2014). PTÖ kapsamında yapılan BBE ile ilgili çalışmaların derinlemesine araştırılmaması ve incelenmemesi PTÖ'nün yararlarının ve eksikliklerini öğrenciler üzerinde hangi derecede geliştiğini belirlenememesi açısından bir eksiklik olarak göze çarpmaktadır.

Proje Tabanlı Öğrenme kapsamında yapılan çalışmalar ilgili alanyazın incelendiğinde, hazırlanan yüksek lisans ve doktora tez çalışmalarının büyük çoğunluğunun belirli bir ünite kapsamında yapıldığı ve genellikle kullanılan yöntemin öğrencilerin ders başarısı ve derse olan tutumu belirlemeye yönelik çalışmalar olduğu görülmüştür. Aktepe ve Aktepe (2009), 90 ilköğretim öğrencisi (4.5.6. ve 7. Sınıf öğrencileri) ile yaptıkları araştırmada, Fen ve Teknoloji ders öğretmenlerinin sınıf içerisinde kullandıkları öğretim yöntemlerini belirlemek için öğrencilerin anket yanıtlamalarını sağlamışlardır. Anket sonuçlarına göre, öğrencilerin \%17'si öğretmenlerinin derste proje çalışmasını hiç yapmadıklarını, \%67'si öğretmenlerinin derste ara sıra proje çalışmalarını yaptıklarını ve \%33'ü öğretmenlerinin her fırsatta proje çalıșmalarını kullandıklarını belirtmişlerdir. 
İlgili literatür dikkatlice incelenmiş ve Fen ve Teknoloji ders saatleri dışında ilgili ders kapsamında, öğrenciler tarafından gerçekleştirilen proje çalışmalarına ilişkin herhangi bir araștırmaya rastlanamamıștır. Sayılan nedenler doğrultusunda bu araștırmanın yürütülmesinde Proje Tabanlı Öğrenme Yaklaşımı temel alınmıştır. Araştırmanın ders dışında yapılmasının gerekçesi ise sınırlı gruplar ile yapılan ders dışı egzersiz çalışmalarının öğrencilere olan etkilerini Fen ve Teknoloji dersi kapsamında belirlemektir. Okul saatleri dışında gerçekleştirilen proje çalışmalarının öğrencilerin derse bakış açıları kapsamındaki görüşlerini belirlemek önemli görülmektedir.

$\mathrm{Bu}$ araștırma ile okul sonrasında Fen ve Teknoloji dersi kapsamında gerçekleştirilen egzersiz çalışmalarına gönüllü olarak katılan öğrencilerin sürece yönelik görüşleri belirlenmeye çalışılmıştır. Araştırma proje tabanlı öğrenme yaklaşımı özelliklerine dikkat edilerek gerçekleştirilmiştir. Bu araştırmanın temel amacını, proje çalışmalarına ders dışı egzersizler kapsamında katılmış öğrencilerin Fen ve Teknoloji dersine yönelik görüşlerini tespit etmek için öğrencilerle yapılan görüşmeler ve gözlem çalışması oluşturmaktadır. Bu araştırma ile Fen ve Teknoloji dersi kapsamında okul saatleri dışında gerçekleştirilen proje çalışmalarının alandaki bu tür çalışmaların eksikliğini doldurması düşünülmektedir.

\section{Araștırmanın Amacı ve Önemi}

Bu araştırmanın genel amacı, ilköğretim ikinci kademede öğrenim gören öğrencilerin ders dışı egzersiz kapsamında katıldıkları proje çalışmaları bağlamında Fen ve Teknoloji dersine ilişkin görüşlerini belirlemektir.

Araştırmacının amacına bağlı olarak problem cümlesi şu şekilde belirlenmiştir: İlköğretim ikinci kademede öğrenim gören öğrencilerin ders dışı egzersiz kapsamında katıldıkları proje çalışmaları bağlamında Fen ve Teknoloji dersine ilişkin görüşleri nelerdir?

Problem cümlesi dikkate alınarak araştırma kapsamında aşağıda maddeler halinde belirtilen alt problemlere yer verilmiştir:

1. Proje çalışmalarına katılan öğrencilerin, proje sürecine yönelik görüşleri nedir?

2. Proje çalışmalarının gerçekleştirildiği sınıfın yapısı ve proje çalışmalarına katılan öğretmen ve öğrencilerin süreç içerisindeki rolleri nelerdir?

Araştırmanın amacı, problem durumu ve alt problemler dikkate alındığında okullarda gerçekleştirilen proje çalışmalarına ilişkin bir fikir edinilebilir. Bu kapsamda, derslerde proje tabanlı öğrenme yaklaşımının kullanılması, öğrencilerin yaşam becerilerinin ve bilişsel işlem becerilerinin gelişmesinde, tutumlarının pozitif yönde olması, öz-yeterlik ve başarma duygusu gibi becerilerin ve özelliklerin gelişmesine katkılar sunabilir.

Proje tabanlı öğrenme ve buna bağlı olarak yürütülen derslerden sonra öğrencilerin daha aktif olmaları ve kendileri bizzat sürecin içerisinde yer alarak ürünleri oluşturmaları öğretimin etkililiği açısından önemlidir (Yurtluk, 2003). Bu çalışmada proje tabanlı öğretimin genel hedeflerinin öğrencilerde kazanılıp kazanılmadığının ortaya çıkarılması açısından önem taşımaktadır. Öğrencilerin proje yapım sürecinde Fen ve Teknoloji dersi açısından, plan yapabilme, bütçe kontrolü gerçekleştirebilme, eleştirel düşünebilme, problem çözebilme, iş birlikli çalışabilme başarma isteği ve duygusu, derse olan ilginin artışı gibi beceri ve özelliklerin süreç sonunda geldiği noktayı yansıtması açısından önemlidir. Öğrencilerin ders saatleri dışında, okuldan sonra Fen ve Teknoloji dersi kapsamındaki konulara ilișkin proje çalışmalarına katılması ve bu sürece yönelik değerlendirmelerinin alınması, yapılan çalışmaların yararlı olup olmadıkları hakkında bilgi vermesi açısından önem arz etmektedir. Bu araştırma ile alanda okul saatleri dışında gerçekleșen bu tür faaliyetler ile ilgili bir boşluğun doldurulması önemli olarak değerlendirilmektedir.

\section{Araştırmanın Modeli}

\section{YÖNTEM}

$\mathrm{Bu}$ araştırmada Nitel araştırma yaklaşımı benimsenmiştir. Araştırma Nitel Araştırma yaklaşımlarından "Durum Çalışması" deseni şeklinde düzenlenmiştir. Durumlar çeşitli formlarda karşımıza gelebilir. Bir grup, birey ya da kurum çalışılan durumlara örnek teşkil edebilir. Bu çalışmada olduğu gibi nitel durum çalışmasının en temel özelliği bir ya da birkaç durumun 
bütüncül yaklaşımla incelenmesidir. Durum çalışması nitel araştırmada çok yaygın olarak kullanılan bir yaklaşımdır (Yıldırım ve Şimşek, 2011).

\section{Çalışma Grubu}

Araştırma, 2011- 2012 eğitim- öğretim yılı güz döneminde, Ankara ili, Keçiören ilçesinde bulunan, bir ilköğretim Okulu'nda 6. sınıfta öğrenim gören iki öğrenci, 7. sınıfta öğrenim gören üç öğrenci ve 8. sinıfta öğrenim gören iki öğrenci olmak üzere toplam yedi öğrenci ile yürütülmüștür. $\mathrm{Bu}$ öğrenciler ile proje çalışmalarının yürütülmesi öğrencilerin istekli olmaları sonucu gerçekleştirilmiştir. Çalışma ilgili eğitim öğretim yılının güz döneminde öğrenciler ile 8 haftada tamamlanmıştır. Çalışmada örneklem belirlenirken, amaçlı durum örnekleme yöntemlerinden, tipik durum örneklemesi kullanılmıştır. Araştırmacı bir uygulamayı tanıtmak istediğinde uygulamanın gerçekleştirildiği bir dizi durum içerisinden en tipik olanlarını belirleyerek onları çalışabilir (Yıldırım ve Şimşek, 2011). Tipik durumların seçiminde genellikle bu konuda bilgi sahibi bireyler veya kurumlar, bu konularda hazırlanmış çeşitli veri tabanları veya araştırma sonuçları yardımcı olabilir. Araştırmanın gayesini, belirli bir alan hakkında fikir sahibi olmak veya bu alan, konu, uygulama veya yenilik konusunda yeterli bilgi sahibi olmayanları bilgilendirmektir (Patton, 1987). Araştırma yapılan eğitim kurumunda daha önce bu tür bir çalıșma yapılmamıștır. Yapılan bu egzersiz çalışmalarının süreç sonunda öğrencilerde bıraktığı izlenimleri ortaya çıkarmak için tipik durum örneklemesi tercih edilmiştir.

\section{Veri Toplama Araçları}

Araştırmada proje tabanlı öğrenme yaklaşımı çerçevesinde gerçekleştirilmekte olan ders dışı proje çalışmalarının etkin bir şekilde yürütülüp yürütülmediğine ilişkin olarak bir gözlem formu hazırlanmıştır. Görüşme formunun hazırlanma sürecinde öncelikle nitel araştırma konusunda uzman olan iki öğretim görevlisinin görüşüne başvurulmuştur. Alan uzmanlarından gelen dönütlere göre görüşme formu üzerinde değişiklikler yapılarak görüşme formuna son hali verilmiştir. Çalışmaların yürütüldüğü mekân, bir video kayıt cihazı ile gözlemlenmiştir.

Görüşme soruları hazırlanmadan önce araştırma konusuyla ilgili yapılmış olan çalışmalar ayrıntılı olarak incelenerek taslak görüşme soruları hazırlanmıştır. Taslak sorular uzman görüşü ile geliştirilmiş ve alt problemlerle ilişkilendirilerek ele alınmış ve uzman görüşüne göre alternatif sorular ve sondalar eklenerek geliştirilmiștir. Görüşme formuna giriş bölümü de eklenerek sorular alt problemlere göre gruplandırılmıştır. Hazırlanan soruların anlaşılır olup olmadığının kontrolü için iki öğrenci tarafından okunmuş ve gerekli düzeltmeler yapılmıştır. Bu şekilde tutarlı ve inandırıcı bir görüşme formu hazırlanmaya çalışılmıştır. Yarı yapılandırılmış görüşme formunda bulunan sorular genel olarak 1. proje çalışmalarının amacı 2. proje çalışmalarında kullanılan materyallerin ve yöntem/tekniklerin değerlendirilmesi 3. öğrencilerin fen ve teknoloji dersine katkısı ve diğer derslere olan bakış açılarının belirlenmesi temalar başlığı altında özetlenebilir.

Araştırmada veri toplama amacıyla öğrenci görüşlerini belirlemek için ağırlıklı olarak açık uçlu sorulardan oluşan yedi soruluk görüşme formu hazırlanmıştır. Sorular farklı başlıklar altında iyi organize edilmeye çalışılmış ve alt problemlerle görüşme soruları ilişkilendirilmiş, açık ve kapalı uçlu sorular harmanlanmıştır. Bilgi içerikli soruların sorulmasından kaçınılmıș, kolay ve olumsuz duygular uyandırmayacak türde sorular hazırlanmıştır. Bu görüşme formu ilgili alan uzmanlarının görüşleri doğrultusunda birçok kere değişikliğe uğramış ve gerekli düzeltmeler yapılarak görüşme formuna son hali verilmiştir.

\section{Uygulama Süreci}

Bu çalışma süresince dört adet proje üretimi söz konusudur. Projelerin tamamı ders sonrasında yapılan çalışmalar ile okulda hazırlanmıştır. Burada öğrenciler kodlanmıştır. 
Proje Konusu

Akıllı Trafik Sistemi

Yaşamımızdaki Elektrik

Ayakkabının Kliması

Isı ve Enerji Aktarımı
Proje Kodu

P1

P2

P3

$\mathrm{P} 4$
Öğrenci Kod

Ö1 ve Ö2

Ö3 ve Ö4

Ö5

Ö6 ve Ö7

P1 kodlu projede araştırmanın amacı, "Kırmızı ışıkta beklemeyerek, aracını kullanan sürücülerin otomatik olarak durmalarını sağlamak" olarak öğrenciler tarafından belirlenmiştir. Bu amacın gerçekleştirilmesine yönelik olarak öğrenciler tarafından belirlenen hedefler: "Kırmızı ışık ihlali yapan sürücülerin kural ihlali yapmalarının önüne geçmek, "Işık ihlali sebebiyle oluşan kazaların önüne geçmek", "Oluşma riski olan kazalar sonucunda meydana gelebilecek yaralanmalar ve ölüm olaylarının önüne geçmek", "İnsanların trafik kurallarına uymalarını sağlayarak, bu bilince erişmelerini kazandırmak" şeklindedir.

P2 kodlu projede araştırmanın amacı, "daha az kayıpla elektrik enerjisinden daha fazla yararlanmak" olarak öğrenciler tarafından belirlenmiştir. Bu amacın gerçekleştirilmesine yönelik olarak öğrenciler tarafından belirlenen hedefler: "elektrik enerjisinden maksimum fayda sağlamak", "elektik kullanımındaki fatura bedellerinin düşük olması" şeklindedir.

P3 kodlu projede araştırmanın amacı, "Sıcak havalarda terleyen ve bu nedenden dolayı terleyen ayakların havalandırmasını sağlamak" olarak öğrenciler tarafından belirlenmiştir. Bu amacın gerçekleștirilmesine yönelik olarak, "ayakların havalandırılmasını sağlamak", "ayakların kokmasını engellemek" hedefler olarak öğrenciler tarafından belirlenmiștir. Bu proje çalışmasında, soru-cevap tekniği yoğun olarak kullanılmıștır.

P4 kodlu projede araştırmanın amacı, "Isı enerjisinden daha verimli yararlanmak" olarak öğrenciler tarafından belirlenmiştir. Bu amacın gerçekleștirilmesine yönelik olarak belirlenen hedefler: "ısı enerjisinden elde edilen enerjinin daha verimli kullanılması", "ısı enerjisinden daha fazla yararlanılması" şeklindedir. Öğrencilerin proje çalışmalarındaki verimliliklerini ve yaratıcılıklarını artırmak için yapılan proje çalışmalarının (P1, P2, P3 ve P4) tamamında, beyin fırtınası, altı şapka düşünme tekniği, kavram haritası, zihin haritası ve soru-cevap yöntem ve teknik olarak kullanılmıştır.

Proje çalışmalarında izlenmesi yararlı olan aşamalar bulunmaktadır. Akdeniz (2007), proje yapım süreçlerinde takip edilmesi gereken dört aşamadan bahsetmektedir. Bunlar; planlama, geliştirme, yürütme ve rapor aşamaları şeklinde özetlemektedir.

$\mathrm{Bu}$ çalışmada da yukarıda sıralana aşamalara dikkat edilerek çalışmalar yürütülmüştür. Proje tabanlı etkinliklerle ilgili öğrencilerin uygulama sürecinde izledikleri aşamalar şunlardır: Proje Aşamalarının Belirlenmesi: Proje çalışmalarında belli bir plan oluşturulmuştur. Yapılan tüm çalışmalar tüm ayrıntıları ile bu planda belirtilmiştir. Proje çalışmaları hafta içerisinde, okuldaki dersler bittikten sonra öğrencilerle gönüllülük esasına dayalı olarak yürütülmüştür. Bu bağlamda proje çalışmaları okul çıkışında günde iki ders saati olacak biçimde gerçekleştirilmiştir. Proje yapım aşamaları şu şekildedir: Proje konusunun belirlenmesi, projenin bilimsel alt yapısı için gerekli olan akademik çalışmaların tamamlanması, proje taslağının bitirilerek gerekli malzemelerin temin edilmesi, projenin detaylarının düşünülerek gerekli olan malzemeler kullanılarak, projenin çalışıp çalışmadığının denenmesi, proje çalışmalarının sonlandırılması.

Proje Konusunun Seçimi: Öğrenciler, doğal çevresini ve yaşamlarını düşünerek bir proje geliştirmişlerdir. Proje konularının belirlenmesi öğrencilere bırakılmıștır. Öğretmen öğrencileri yönlendirici ve rehberlik edici bir göreve sahip olmuştur. Bu bağlamda, çalışma süresince öğretmen rehberliğinde öğrenciler tarafından dört proje hazırlanmıştır.

Amacın Belirlenmesi: PTÖ yaklaşımı kapsamında; bir proje için amaç genellikle bir tanedir. Projenin amacına bağlı olarak hedefler öğrenciler tarafından belirlenmiştir. Hedeflerin, amacı tamamlayıcı bir göreve sahip olmaları öğretmen rehberliğinde öğrenciler tarafından sağlanmıştır. Öğrenciler kendi projelerini belirlerken günlük yaşamda karşılaştıkları bir problemden yola çıkmışlardır. Öğrenciler, bu problem ışığında projelerinin temel amacını belirlemişlerdir.

Uygulama: Proje ile ilgili planlama, teorik ders kısmı bitirildikten sonra proje için uygulama aşaması başlatılmıştır. Yapılan çalışmalar öğretmen rehberliğinde, öğrenciler tarafından 
tamamlanmıştır. Proje çalışma sürecinin ilk iki haftasını (12 ders saati) teorik dersler oluşturmaktadır. Bu derslerde, projenin ne olduğu, proje çalışmalarında nelere dikkat edilmesi gerektiği, proje ürünlerini hazırlama sürecinde yararlanılacak kaynakların neler olduğu, literatür taramasının nasıl yapılacağı vb. gibi sorulara yanıt verebilmek için öğretmen tarafından teorik dersler verilmiş̧tir. Araştırmanın geri kalan altı haftası ise (36 ders saati) pratik proje hazırlama süreci olarak gerçekleştirilmiştir.

Proje Sunumunun Gerçekleștirilmesi: Yapılan projeler ile ilgili bir rapor, projeleri gerçekleştiren öğrenciler tarafından hazırlanarak raporların somut bir şekilde sınıfa sunumu gerçekleștirilmiştir. Bu kapsamda P3 numaralı proje Ö5 kodlu öğrenci tarafından raporlaştırılarak sunumu gerçekleştirilmiștir. P1 numaralı proje Ö1 ve Ö2, P2 numaralı proje Ö3 ve Ö4, P4 numaralı projenin raporu Ö6 ve Ö7 kodlu öğrenciler tarafından hazırlanarak, sunumları gerçekleştirilmiştir. Bu kapsamda dört farklı proje hazırlandığından dört proje raporu öğrenciler tarafından yazılmıștır.

Projenin Değerlendirilmesi: Projelerin sunumları gerçekleştirildikten sonra sınıf içerisinde öğretmen ve öğrenciler arasında bilimsel tartışmalar şeklinde projeler değerlendirilmiştir. Diğer öğrencilerin görüşleri alınmıştır. Çalışmanın hedeflenen amaca ulaşıp ulaşmadığı yapılan uygulamalar ve denemeler ile denetlenmiştir.

\section{Verilerin Toplanması}

Öğrenciler ile proje çalışmalarına başlamadan önce onlara araştırma ile ilgili bilgi verilerek; öğrencilerin ailelerinden, öğretmenlerinden ve okul idaresinden ilgili çalışmaların yapılabilmesi için gerekli izinler alınmıştır. Daha sonra yapılan gözlem ve görüşmeler kayıt altına alınmıștır. Öğrencilerle yapılan görüșme öncesi gerekli izinler alınmıș, okul idaresi ve veliler proje çalışmasıyla ilgili bilgilendirilmiştir. Görüşmelerin analizinden önce öğrencileri tanımaya yönelik ve çalışma öncesinde öğrencilerin çalışma sonuçlarını etkileyebilecek farklı özellikler bulunmaktadır. Görüşmeler, çalışmaya katılan öğrenciler arasında gönüllülük esasına göre gerçekleştirilmiştir. Görüşmeler, araştırmaya katılan istekli öğrencilerden üçü 7. Sınıfa devam etmekte ve ikisi 8. Sınıfa devam etmektedir. Görüşme yapılan öğrencilerin hiçbiri sınıf tekrarı yapmamıștır. Aynı sınıf seviyesinde yaş farklılıkların olduğu görülmektedir. Öğrencilerin hiç biri geçtiğimiz senelerde ders saatleri dışında proje çalışmalarına katılmadıklarını belirtmişlerdir. $\mathrm{Bu}$ anlamda görüşme yapılan öğrencilerle ilgili değişkenlerin benzer olduğu söylenebilir. Öğrenciler, ilk kez bu yıl proje çalışmalarına Fen ve Teknoloji dersi kapsamında katıldıklarını belirtmişlerdir. Görüşmelerde öğrencilerin rahat ve samimi hissetmelerine özen gösterilmiştir. Sınıf ortamının gözlemlenmesi video kayıt cihazı ile gerçekleştirilmiştir. Öğrenciler ile randevu alınarak görüşmeler gerçekleştirilmiştir. Görüşmelerde gizlilik temin edilmiştir. Bazı öğrencilerin verdikleri cevaplarda öğretmenlerinden çekinebilecekleri düşünülmüștür. Proje çalışmalarında görev alan beş öğrenci ile gönüllük esas alınarak yarı yapılandırılmış görüşme gerçekleştirilmiştir. Öğrenciler ile yapılan görüşmelerin verileri ses kayıt cihazı ile kayıt edilmiştir. Görüşmelerde öncelikle genel sorular ile başlanarak karşılıklı ve etkileşimli bir iletişim süreci oluşturulmaya çalışılmış ve daha sonra sorular özele ve çalışmaya indirgenmiştir. Öğrencilerle yapılan her bir görüşme yaklaşık 30-40 dakika sürmüştür. Görüşmeler sırasında elde edilen veriler ses kayıt cihazı kullanılarak kaydedilmiştir. Kaydedilen veriler düzeltme yapılmadan bilgisayar ortamına aktarılmıștır.

Yapılandırılmış gözlem çalışması olarak, gözlenecek durum ile ilgili daha iyi bir yapılanma ve sistematik bir yaklaşım kullanılmıștır. Bu anlamda, gözlem öncesi, gözlemcinin bilgi toplaması ve kaydetmesi için oluşturulmuş bir gözlem formu ve kodlama sistemi hazırlanmıştır. Yapılan çalışmalarda hiçbir rol almayan ancak araştırmacı olduğu grup üyeleri tarafından bilinen araştırmacı gözlemci (Yıldırım ve Şimşek, 2011), olduğu için katılımcı gözlemci tarzında bir gözlem çalışması gerçekleştirilmiştir. Yapılan çalışmaların gözlem verileri sırasıyla 24.10.2011 (2 saat), 14.11.2011 (2 saat), 12.12.2011 (2 saat) ve 19.12.2011 (2 saat) olacak şekilde gerçekleştirilmiştir. 


\section{Verilerin Analizi}

Araştırma verilerinin analizi için "Betimsel analiz ve İçerik analizi " kullanılmıştır. Görüşme verileri "Betimsel Analiz" șeklinde analiz edilmiştir. Betimsel analiz yaklașımına göre (Yıldırım ve Şimşek, 2011) görüşülen ya da gözlenen bireylerin görüşlerini çarpıcı bir biçimde yansıtmak için doğrudan alıntılara yer verilmiştir.

Araştırmanın gözlem verileri içerik analizine tabi tutulmuştur. Araştırmada toplanan verileri açılayabilecek kavramlara ve ilişkilere ulaşabilmek için içerik analizi kullanılmıştır. Verilerin analizi nitel araştırmalarda önemli görülen açıklık, netlik, akıcılık, yorumlama gibi özelliklere uygun şekilde yapılmaya çalışılmıştır. Betimsel analiz sürecinde tematik çerçeve oluşturularak verile işlenmiş ve bulgular yorumlanmıștır. İçerik analizinde de veriler bölümlere ayrılarak ve karşılaştırılarak incelenmiştir. Veri analiz sürecinde kodların ve temaların araştırma problemleriyle ilişkilendirme ve yorumlama sürecinde alan uzmanları ile sık sık bir araya gelinerek birlikte çalışılmış ve verilen dönütler doğrultusunda kodlamada bulunan tüm eksiklikler giderilmeye çalıșılmış ve temalar ilgili kodlara göre yeniden düzenlenmiştir.

\section{Güvenirlik ve Geçerlik}

Tüm nitel araştırmalarda olduğu gibi bu çalıșmanın geçerliği için "İç geçerlik ve Dış geçerlik" kavramları dikkate alınarak gerekli düzenlemeler yapılmaya çalışılmıştır. Geçerliğin sağlanabilmesi için her iki geçerliğinde sağlanması üzerinde durulmuştur.

Araştırmanın iç geçerliğinin sağlanması alan uzmanından yararlanarak, verilerin elde edildiği ortam dikkate alınarak yapılmıştır. Bulgular dikkatle incelendiğinde elde edilen verilerin anlamlı olduğu ve bir bütünsellik taşıdığı görülmektedir. Elde edilen bulguların daha önce oluşturulmuş olan kavramsal çerçeve ile uyumlu olduğu görülmüştür. Çalışmanın verileri değerlendirildiğinde teorik olarak aktarılana yakın bir pratik yapma olanağı elde edilmiştir.

Araştırmaya katılan katılımcılar ilköğretim ikinci kademe öğrencileridir. Öğrenciler ilköğretim I. Kademenin 4. sınıfından itibaren bu konuları görmeye başlamaktadırlar. Dolayısı ile yapılan proje çalışmaları ile araştırmanın gerçekçi bulunduğu katılımcılar tarafından teyit edilmiştir. Araştırmanın dış geçerliğinin sağlanması için; örneklemin ve çalışma ortamının ve süreçlerinin başka örnekler ile karşılaştırma düzeyleri, araştırmanın genelleme amacı taşıyı taşımadığı, örneklemin ortamın ve kavramsal çerçevenin seçimi, çeşitlendirilme durumları ve olası genelleme durumları açılarından incelenmiştir. Araştırmada dış geçerliğin sağlanabilmesi için ayrıca; Araştırma örnekleminin başka bir örneklem büyüklüğü ile karşılaştırması yapılmıştır. Bir doktora tez çalışması detaylı bir şekilde analiz edilmiştir. Söz konusu tez çalışması incelendiğinde ilgili çalışmada örneklem büyüklüğünün 10 olduğu görülmüştür. Bu çalışmada ise örneklem büyüklüğü 7'dir.

Nitel çalışmalarda amaç genelleme yapmak olmadığından dolayı iki uzman görüşü alınmıștır. Uzmanların analizi sonucu örneklem büyüklügünün yeterli olduğu yönünde gerekli olan dönütler alınmıştır. Bu araştırma genelleme gibi bir kaygı taşımamaktadır. Örneklem ve kavramsal çerçeve düşünüldüğünde, yapılan araştırma konusunun genelleme etkileri hissedilmemektedir. Genelleme yapılabilmesi için, çeşitli faktörlerin belirli kıstaslara göre yapılması gerekirdi. Örneğin, kız-erkek oranı, akademik başarı düzeyleri vb. gibi faktörlerin araştırmaya başlamadan önce bu faktörlerin varlıkları analiz edilmeliydi. Bu çalışmada bu tür bir analiz yapılmadığı için genelleme kaygısı taşımamaktadır.

Araştırmanın geçerliği sağlandıktan sonra güvenirliğinin sağlanıp sağlanmadığı üzerine çalışılmıştır. Bunun için araştırma, analiz edilen verilerin kodlayıcı güvenirliği, zamana ve gözleme bağlı olarak güvenirlik yönlerinden incelenmiştir.

$\mathrm{Bu}$ araştırmada, ham görüşme verileri iki uzman tarafından incelenmiştir. Alan uzmanları tarafından birbirinden bağımsız olarak temalar ve kodlar oluşturulmuștur. Görüşme formundan elde edilen kodların ve temaların güvenirliğini belirlemek amacıyla Miles ve Huberman (1994) "uyum yüzdesi" formülü kullanılmıștır. Uyum yüzdesi= (Uzlaşma)/(Uzlaşma+Uzlaşmama)X100 șeklinde formüle edilmektedir. Bu formüle göre görüşme formundaki uyum yüzdesi 83,36 olarak bulunmuştur. Gözlemlerden elde edilen verilerde alan uzmanları tarafından ayrı ayrı analiz edilmiștir. Yukarıda verilen uyum yüzdesi formülene göre içerik analizine tabi tutulan verilerin kodlayıcı uyum yüzdesi 85,68 olarak bulunmuştur. Bu değerler görüşme ve gözlem verilerinin 
birbirinden bağımsız uzmanlar tarafından analiz edilmesi ile araştırmanın güvenirliğinin artırıldığını ortaya koymaktadır.

$\mathrm{Bu}$ araştırma zamana bağlı güvenirlik açısından problemler taşıyabilir. Çünkü çalışılan öğrenci grubu ilköğretim ikinci kademe öğrencileri olduğundan öğrencilerin davranışları değişken olabilmektedir. Dolayısıyla bu durum çalışmalar sırasında eksikliklere yol açabilmektedir. Burada ayrıca Hawthorne etkisinin ve uygulayıcı yanlılığının etkilerinin olduğu düşünülebilir. Ancak uygulayıcı öğretmen öğrencilerin ders öğretmenleridir. Yani öğrencileri tanıyan ve bilen kişidir. Yapılan gözlemler sonucunda, uygulama sonunda ve süreç içerisinde öğrenciler de geçici olarak performans artışı görülmediği tespit edilmiştir. Dolayısı ile araştırma süresince Hawthorne etkisi ya da uygulayıcı yanlılı̆̆ı minimum seviyede tutulmaya çalışılmıştır. Güvenirliği artırmak amacı ile çalışmada araştırma soruları, alt problemler, sondalar, alternatif sorular, proje çalışma süreçleri etkin bir şekilde anlatılmıştır. Araştırmanın objektif olabilmesi için yorumların çalışmada yer verilmemesine özen gösterilmiștir. Araştırmada farklı görüşlere yer verilmeye çalışılmıştır. Araştırma sürecinde video çekimleri ve ses kayıt cihazı kullanılmıştır.

\section{BULGULAR}

$\mathrm{Bu}$ bölümde öğrencileri, öğretmeni ve proje çalışmalarının yapıldığı mekân ile ilgili gözlemden elde edilen verilere yer verilmiştir. Bunun yanında öğrenciler ile yapılan görüşme verileri de bu bölümde incelenmektedir.

\section{Alt Probleme Yönelik Bulgular}

Araştırmanın birinci alt problemini yanıtlayabilmek için katılımcılar ile gerçekleştirilen görüşmeler analiz edilmiştir. Çalışmaya katılan öğrencilerden 5’i ile gönüllülük esasına dayalı olarak görüşmeler gerçekleştirilmiştir.

Bulguların analizi sonucu 1. Alt probleme ilişkin bulguların betimsel analizi için araştırmacılar tarafından kategoriler belirlenmiş ve araştırma sonuçları bu başlıklar altında sunulmuştur.

1. Alt Problem kapsamında belirlenen kategori başlıkları şunlardır:

*ders dışı proje çalışmalarının temel amacı,

* proje çalışmalarının genel amacı,

*proje çalışmalarında kullanılan yöntem ve teknikler,

*projeler için kullanılan ya da hazırlanan materyaller,

*proje çalışmalarında öğrenilen yeni bilgilerin değerlendirilmesi ve yararlanılması,

* proje çalışmalarına katılımdan sonra Fen ve Teknoloji dersi başarısı ile ilişkilendirme,

* proje çalışmalarının diğer derslere olan etkileri.

1.Alt Problem ile ilgili öğrenci görüşleri yukarıda verilen kategoriler ıșığında çözümlenmiștir.

\subsection{Ders dışı proje çalışmalarının temel amacı:}

Öğrenci görüşleri kapsamında, ders dışı proje çalışmalarının temel amacının öğrenciler tarafından ne şekilde algılandığı ile ilgili bulgular 1 . Alt problemin ilk kategorisini oluşturmaktadır. $\mathrm{Bu}$ kapsamda, Ö1 ve Ö2 ve Ö6 kodlu öğrenciler, proje çalışmasının amacının ders öğretmeni tarafından açıklandığını ve amacın hayatımızdaki işleri kolaylaştırmak olduğunu belirtmişlerdir. $\mathrm{Bu}$ öğrenciler, amacın tüm öğrenciler tarafından aynı şekilde algılandığını düşünmektedirler. Bunun nedenini ise tüm öğrencilerin aynı ortamda bulunmalarına bağlamışlardır. Ö5 kodlu öğrenci, proje çalışmasının amacının dersin öğretmeni tarafından açıklandığını belirtmiştir. Ö5 kodlu öğrencinin düşüncesi aynen aktarılmıştır: "Yapacağımız ürünün bize faydalı olması, vatana millete faydalı olması gereklidir." Aynı zamanda proje çalışmalarının amacının diğer öğrenciler tarafından da aynı şekilde anlaşıldığını düşünmektedir. Ö7, proje çalıșmalarının amacının dersin öğretmeni tarafından aktarıldığını belirtmiştir. Ancak bazı öğrencilerin ders sırasından sık sık soru sormalarından dolayı dersin amacının tüm öğrenciler $(n=3)$ tarafından aynı şekilde anlaşılmadığını düşünmektedir. Ö7 kodlu öğrencinin bu soruya verdiği yanıt şu şekildedir: "Öğretmenimiz bazı derslerimizde amacı açıklamasına rağmen, bazı öğrenciler çalışmaların amaçları ile ilgili olarak ara sıra soru soruyorlardı." Öğrencilere sorulan katıldığınız ders dışı proje çalışmalarının temel amacı sizce neydi sorusu, "hayatımızdaki işlerin kolaylaşması, ürünün faydalı 
olması, ülkemize faydalı olması" şeklinde özetlenebilir. Proje süreci açısından değerlendirildiğinde öğrencilerin büyük kısmının (4 öğrenci) proje yapmalarının amaçlarını benimseyerek süreçte bulundukları ancak bir kısmının (3 öğrenci) ise amacını bilmeden sürece katıldıkları söylenebilir. Proje amacını düşünerek ve benimseyerek projelerini yürütmüş olan öğrencilerin süreçte daha aktif ve başarılı oldukları, hazırlanan proje ürünlerinin çalışması ortaya koymuştur.

\subsection{Proje çalışmalarının genel amacı:}

Ö1, çevrelerinin temiz olması gerektiğini bunun içinde bir ürüne ihtiyaçlarını olduğunu belirtmiştir. Bunun yanında öğretmenlerinin iyi bir eğitim vermeleri gerektiğini ve sorunlarının azaltması gerektiğini belirtmiştir. Ö2, eğitimlerini daha kolay bir biçimde almalarını sağlaması gerektiğini düşünmektedir. Öğretmenin sahip oldukları becerilerini ortaya çıkarması gerektiğini belirtmiştir. Çalışmanın okul için temel amacının ise okulun sorunlarını gidermesi olduğunu ve okullarının daha güzel bir okul olmasını sağlaması gerektiğini belirtmiştir. Veli yönünden, öğrencilerine olan güvenlerinin daha fazla olmasını sağlaması gerektiğini belirtmiştir. Ö5,proje çalışmalarının genel amacının, öğrencilere yararlı olmasını ve öğretmenlerine velilerine sevinç ve gurur katması gerektiğini belirtmiştir. Okulu açısından, isimlerinin daha fazla duyuracağını ve eğitim kalitesinin yükselmesine yardımcı olması gerektiğini belirtmiștir. Proje yarıșmalarında ödül almalarını sağlaması gerektiğini düşünmektedir. Ö7, proje çalışmalarının amacının, eğitimli bir Türkiye için yeni materyaller geliştirmek olması gerektiğini düşünmektedir. Öğrenciler tarafından anlaşılacak şekilde anlatımı kolaylaştırmanın, öğretmene bu yönde bir görev bilinci getireceğini ortaya koymuştur. Proje çalıșmalarının amacının okul yönünden; okulun isminin daha fazla duyulacağını ve okullarındaki eğitim kalitesinin artacağını düşünmektedir. Velileri yönünden çocuklarına olan güvenin artırması gerektiğini belirtmiştir. Ö6, bu soru hakkındaki düşüncesini şu şekilde açıklamıştır: "Proje çalışmaları bana göre öğrenci açısından, dersin daha iyi anlaşılmasına yardımcı olmalıdır." Öğretmen açısından dersin amacının dersi daha iyi biçimde ve öğrencinin el becerisini görmesine olanak sağlaması olarak belirtmiştir. Okul yönünden ise proje çalışmalarının temel amacının bulunmadığını düşünmektedir. Proje çalışmalarının genel amacı sizce ne olmalıdır sorusu, iyi eğitim verme, sorunların azaltılması, yararlı olması, velilere gurur kaynağı olma, ödül alma, okulun isminin duyurulması, eğitim kalitesinin artması şeklinde özetlenebilir.

\subsection{Proje çalışmalarında kullanılan yöntem ve teknikler:}

Bu çalışmada öğrenciler proje çalışmalarına yönelik olarak, zihin haritası, soru-cevap ve kavram haritası gibi yöntemleri ve beyin fırtınası, altı şapka düşünme gibi teknikler kullanmışlardır. Bu yöntem ve tekniklere ilişkin öğrenci görüşleri şu şekilde özetlenebilir. Görüşmeye katılan öğrencilerin tümü $(n=5)$, proje çalışmalarında kullanılan yöntemlerin kendilerini aktif ve etkin kıldıklarını belirttiler. Bununla birlikte çalışma sürecinde birbirleri ile sık biçimde yardımlaştıklarını belirttiler. Ö5, proje çalışmaları süresince kullanılan yöntemlerden dolayı okula daha sevinçli geldiğini ve diğer derslere olan ilgisinin arttığını belirtmiştir. Ö7, kullanılan yöntem sayesinde eğlenerek öğrendiklerini belirtmiştir. Ö6, iletişim bağlamından kullanılan yöntem ve tekniklerin faydasını gördügünü düşünmektedir. Ö2'nin bu soruya verdiği yanıt şu şekildedir: "Proje çalışmaları sırasında kullandığımız yöntemler sayesinde, arkadaşlarımla daha iyi iletişsim kurdum ve araştırma yaparken daha bilinçli olabilmeyi kavradım." Proje çalışmalarında kullanılan yöntem ve teknikler açısından değerlendirildiğinde öğrencilerin tamamının (n=5) süreçte aktif olarak görev aldıkları ve süreçte çalışmalar süresince etkileşimlerin arttığı ve dersin işlenmesinin daha eğlenceli hale geldiği söylenebilir.

\subsection{Projeler için kullanılan ya da hazırlanan materyaller:}

Öğrencilerin tümü $(n=5)$ kullandıkları materyalleri çevrelerinde kolaylıkla bulabildikleri malzemelerden seçtiklerini ve projeleri ile doğrudan ilgili materyaller edindiklerini belirttiler. Proje çalışmaları kapsamında öğrencilerin, büyüteç, strafor köpük, fon kartonlar, kalem piller, iletken teller, lambalar, ısıtıcı teller, mum vb. gibi materyallerden yararlandıkları gözlemlenmiştir. Ö2, materyalleri uygun ve yeterli gördügünü ancak elinde daha zengin materyaller olduğunda 
daha iyi projeler yapabileceğini belirtmiştir. Ö6 kodlu öğrencinin bu soruya verdiği yanıt aynen aktarılmıştır: "Proje çalışmalarında günlük hayatta işime yaramayacak diye düşündügüm birçok malzemeden yararlandım. Bunun yanında kullandığım malzemelerde çok pahalı olmayan, kolayca bulabildiğim araç gereçlerdi." Projelerin yapımında kullanılan materyaller açısından düşünüldüğünde, öğrencilerin $(n=5)$ çevrelerinde rahatlıkla bulabilecekleri materyalleri seçtikleri bunun yanında bir öğrencinin (Ö2) imkânını daha iyi olması durumunda daha kaliteli projeler üretebileceği söylenebilir.

\subsection{Proje çalışmalarında öğrenilen yeni bilgilerin değerlendirilmesi ve yararlanılması:}

Soru açık uçlu olduğu için öğrencilerin tamamı proje çalışmalarından farklı şekillerde yararlandıklarını dile getirmişlerdir. Buna göre öğrencilerden, Ö1ve Ö5, proje çalışmalarında edindikleri bilgilerden yararlandıklarını belirttiler. Süreçte öğrendiklerinin ilgili dersin sınavlarında soru olarak çıktığını ve soruları doğru olarak yanıtladıklarını belirttiler. Ö2, çalışmalar sonucunda, sınavlarda zorlanmadığını ve herhangi bir etkinlik yapılırken daha istekli ve rahat biçimde yapabildiğini belirtmiştir. Proje çalışmaları sonucunda, elde ettikleri becerileri evlerinde bir alet bozulduğunda tamir etmeye çalıştığını ifade etmiştir. Ö7, Fen ve Teknoloji dersi sınavlarında artık zorlanmadığını, iletişim kurarken daha rahat olduğunu, öğrendiği bilgilerin dersleri anlamasına yardımcı olduğunu belirtmiștir. Ö6, soru sorulunca kısa sürede soruyu anlayabildiğini belirtmiştir. Bunun nedeni olarak, arkadaşlarının yaptığı proje çalıșmalarının da gözlemleri sonucu etkili olduğunu belirtmiştir. Proje çalışmaları sonucunda özellikle proje konusunu iyi anladığını ve evinde sigorta attığında bunu anlayabildiğini ve çözüm üretebildiğini aktarmıştır. Ö1 kodlu öğrencinin bu soruya verdiği yanıt aynen aktarılmıştır: "Proje çalışmalarına katıldıktan sonra bir bilgiye nasıl ulaşılır ve o bilgiyi nasıl kullanabileceğimi öğrendim. Fen derslerinde öğretmen ödev verdiğinde daha verimli çalışmayı öğrendim. Derse sürekli olarak çalışmaya başladı̆̆ımdan, artık sınavlarımda fazla zorlanmıyorum."

1.6. Proje çalışmalarına katılımdan sonra Fen ve Teknoloji dersi başarısı ile ilişkilendirme: Görüşmeye katılan öğrencilerin tümü $(n=5)$, daha önceleri dersteki performanslarının biraz zayıf olduğunu ancak proje çalışmaları sonucunda ders performanslarının arttığını belirttiler. Sınav notlarının artmaya başladığını, öğretmenin herhangi bir konu ile ilgili soru yönelttiğinde daha mantıklı yanıtlar verebildiklerini ve ders başarılarının arttığını belirttiler. Öğrencilerin proje çalışmalarına katıldıktan sonra ki sınav notları incelendiğinde öğrencilerden Ö3, Ö4 ve Ö5.'in notlarında yükselmeler olduğu tespit edilmiştir. Ö3 kodlu öğrenci bu soruyu şu şekilde yanıtlamıştır: "Proje çalışmalarına katıldıktan sonra özgüvenim arttı. Derslerimde daha fazla söz almaya ve ödevlerimi daha istekli yapmaya başladım. Proje çalışmalarından sonra Fen ve Teknoloji dersindeki yazılı notlarımın da yükseldiğini fark ettim."

\subsection{Proje çalışmalarının diğer derslere olan etkileri:}

Genel olarak proje çalışmalarının öğrencilerin diğer derslerdeki başarılarını etkilediği söylenebilir. Ö1, diğer derslerine herhangi katkısının olmadığını belirtmiştir. Ö2, Ö5, Ö6 ve Ö7 proje çalışmaları sonucunda, sadece Fen ve Teknoloji dersi etkisinin kapsamında olmayıp, diğer tüm derslerinde de başarılarının arttığını belirtmiş ve diğer dersleri daha iyi anlamaya başladıklarını ifade etmişlerdir. Ayrıca Ö2, proje çalışmalarının her sene yapılması istediğini ve böylelikle başarılarını artırmak istediğini belirtmiştir. Ö6, proje çalışmalarında etkin düşünmeyi öğrendiğini ve yaratıcı düşünme becerilerinin geliştiğini belirtmiştir. Görüşülen öğrencilerin büyük kısmının $(\mathrm{n}=3)$ proje çalışmaları sonucunda diğer derslerinin de başarılarının arttığı söylenebilir. Öğrencilerden birinin proje çalışmalarının her yıl yapılmasını istemesi uzun vadede öğrencilerin fen ve teknoloji ders bașarılarının yanı sıra diğer ders bașarılarının da olumlu yönde etkileneceği düşünülebilir. Ö5 kodlu öğrencinin yanıtı şu şekildedir: "Proje çalışmalarına katıldıktan sonra dersi sevmeye başladığımı ve diğer derslere de ilgi duymaya başladığımı fark ettim. Diğer derslerimizde de proje çalıșmalarının olmasını isterim. Özellikle sözel olan derslerde bazı konularda çok sıkıllyorum ve bu konularında proje çalışmaları ile işlenebileceğini düşünüyorum." Bunun yanında yalnızca bir öğrencinin (Ö1) diğer ders başarılarında herhangi bir artışın proje çalışmaları sonucunda değişmediği söylenebilir. 


\section{Alt Probleme Yönelik Bulgular}

Araştırmanın ikinci alt problemini cevaplayabilmek için sınıf içerisinde yapılan gözlem çalışması verileri toplanmış ve analiz edilerek yorumlanmıştır. Araştırma kapsamında çalışmanın yapıldığı ortam gözlemlenmiştir. Bunun için bir video-kayıt cihazı kullanılmıştır. Fen ve Teknoloji Öğretmeni video-kayıt cihazı ile çalışmanın yürütüldüğü ortamı gözlemlemiştir. Her bir gözlem süresince yani 40 dakika olacak şekilde yapılmıştır. Çalışmanın yapıldığı ortam bir sınıftır. Okulun laboratuvarı bulunmadığından dolayı proje çalışmaları bir derslikte sürdürülmektedir.

Proje çalışmalarının yapıldığı sınıf ile ilgili aşağıda verilen araştırma soruları ışığında gözlem yapılmıştır. Așağıda verilen sorular yardımı ile yapılan gözlemde, "sınıfın yapısı", “öğretmen ve öğrencinin süreçteki rolü” gibi tematik kodlar altında veriler yapılandırılmıștır.

\section{Sinıfın yapısı:}

Sınıf ortamlarının fiziki durumları proje tabanlı öğrenme kapsamında gerçekleștirilen çalışmalarda önemlidir. Öğrencilerin bu öğrenme yaklaşımına göre çalışacakları ortam öğrenmelerine ve rahat hareket etmelerine ve çalışmalarına uygun olmalıdır. Bu kapsamda proje çalışmalarının yapıldığı sınıfın fiziki durumunu anlatmakta yarar vardır. Proje çalışmalarının yapıldığı sınıf ya da çalıșma mekânlarında ilgili çalıșmaların türüne göre (grup çalışması ya da bireysel çalışma) sınıftaki sıraların ve masaların düzenleri farklılaşmaktadır. Proje çalışmalarının yürütüldügü mekânlarda kullanılacak ya da yararlanılacak araç-gereçlerin düzenli bir biçimde masanın üst kısımlarında yerleştirilmeleri gereklidir. Bunun yanında proje çalışmalarında etkileşim ve iletişimin yoğunluğu göz önüne alındığında öğrencilerin birbirlerinden çalışmanın yapıldığı mekân içerisinde çok uzakta olmamalarına dikkat edilmelidir. Çalışmanın yürütüldügü mekânda proje yapım sürecinde yer almayacak araç-gereçlerin bulunmamasına özen gösterilmesi gereklidir. Bu araştırma sürecinde proje çalışmalarının yürütüldüğü sınıfı ele aldığımızda; sınıfta toplam 12 sıra ve 12 masa bulunduğu belirlenmiştir. Sınıf yapısı itibariyle küçük bir sınıftır. Öğretmen masası duvar tarafında, sınıf tahtasının sağ tarafında yer almaktadır. Sınıftaki öğrenci sıra ve masaları B tipi yerleştirmesine uygun biçimde yapılmıştır. Bu durum öğrencilerin rahat biçimde çalışmalarına olanak sağladığı söylenebilir. Masaların alt gözlerinde ve üst kısımlarında proje çalışmalarında gerekli olan araç-gereçler dışında bir şeylerin olmadığı gözlenmiştir. Sınıf duvarları açık renklerde boyanmıştır. Duvarlarda öğrencilerin çeşitli derslere ait yaptıkları çalışmalar yapıştırılmıştır. Çalışılan ortamda dikkat dağıtıcı nesnelerin olmayışı çalışmaların verimini artırabileceği söylenebilir. Sınıf tahtasının üstünde Atatürk portresi, İstiklal Marşı ve Atatürk'ün Gençliğe Hitabesi yer almaktadır. Proje çalışmalarına toplam 7 öğrenci katılmıştır. Proje çalıșmalarına katılan öğrencilerin tamamı ilköğretim ikinci kademede öğrenim gören öğrenciler olduğu tespit edilmiştir. Proje çalışmaları hafta içerisinde her gün olmak üzere, her bir günde iki ders saati süresince gerçekleştirilmiştir. Sınıf içerisinde, proje çalışmaları süresince öğretmenin öğrencilere yaklaşımı ve öğrencilerin kendi aralarındaki iletişimin olumlu olduğu belirlenmiştir. Öğrencilerin ilgili proje çalışmalarında kullandıkları malzemeleri çalışma süresince masalarının üstlerine düzenli biçimde koydukları belirlenmiştir. Ellerinde olmayan proje malzemeleri birbirlerinden edindikleri gözlemlenmiştir. Proje çalışmalarında kullanılan araç gereçlerin, edinilmesi zor olmayan malzemelerden seçildiği tespit edilmiştir.

Öğretmen ve öğrencilerin süreçteki rolleri:

Öğretmenlerin ve öğrencilerin proje çalışmaları süresince öğretmen ve öğrencilerin süreçteki rollerine ilişkin bilgiler tablo 1'de sunulmuştur.

Tablo 1 incelendiğinde, öğretmenin süreç tanımı; çeşitli kategoriler altında incelenmiştir. Öğretmenin süreçteki rolü: Öğretmen süreçteki rolü; soru sorma, yöneltme, övme, yardım etme, yönlendirici olma ve rehber olma kategorileri altında incelenmiştir.

- Soru sorma: Bu kategori, öğretmen içerik ve işleyiş̧le ilgili, kendi düşüncelerine dayalı olarak, öğrencilere yanıtlayabilecekleri sorular sorduğu ve bu soruların kısa-kapalı uçlu (\% 33.6), uzun açı-uçlu (\%26.6) olduğu belirlenmiştir.

- Yöneltme: Süreç içerisinde öğretmenin (\%3.3) öğrencilerini bir amaca ya da hedefe yönelik olarak yönelttiği belirlenmiştir. 
- Övme: Süreç içerisinde öğretmenin (\%3.3) öğrencilerine verdikleri yanıt sonrasında onları övdügü tespit edilmiștir.

- Yardım etme: Öğretmen çalışma süresince öğrencilerine proje faaliyetleri sürecinde, \%25 oranında yardım ettiği belirlenmiștir.

- Yönlendirici olma: Öğretmen çalışmalar kapsamında (\%25) öğrencileri hedeflerine ve amaçlarına ulaşabilmeleri için onlara rehberlik ettiği belirlenmiştir.

- Rehber olma: Öğretmenin süreç boyunca yapılandırmacı öğretim yaklaşımına uygun olarak hareket ettiği gözlemlenmiștir. Bu kategori doğrultusunda öğretmen doğrudan öğrenciye bilgi sağlayıcı olmayıp, öğrencilerine (\%50) rehberlik yaptığı tespit edilmiştir.

Öğrencilerin süreçteki rolleri: Öğrencilerin süreçteki rol tanımları; "sorulan soruların türleri", "yanıt verme" ve "çalışma düzenleri" şeklinde kategorize edilmiştir.

- Soru türleri: Öğrencilerin süreçteki sordukları soruların; öğrencilerin sordukları sorular (\% 25) prosedür soruları, (\% 37.5) açıklama soruları, (\%12.5) teorik sorular ve (\%12.5) pratik sorular şeklinde olduğu belirlenmiştir.

- Yanıt verme: Çalışma sürecinde öğrencilerin tamamının, öğretmenlerinin sordukları sorulara yanıt verdikleri gözlemlenmiştir.

- Çalışma düzeni: Öğrencilerin tamamının süreç boyunca düzenli bir biçimde çalıștıkları tespit edilmiştir. Bunun yanında öğrencilerin proje çalışmaları süresince, tamamının etkin biçimde görev aldıkları ve hazırlanan projelerde her bir öğrencinin emek verdiği tespit edilmiştir.

Öğretmenin ve öğrencilerin süreçteki rolleri incelendiğinde öğretmen ve öğrencilerin rolleri farklılık göstermesine rağmen genel olarak aynı yoğunlukta çalıştıkları ve proje sürecinde etkin biçimde rol aldıkları söylenebilir. Sürecin tamamı ele alındığında, öğretmenin sorumluluklarının öğrencilerden bazı durumlarda daha fazla olduğu gözlenmiştir. Dolayısıyla proje tabanlı öğrenme yaklaşımında öğretmen rolünün ve rehberliğinin etkisinin ve öneminin çalışma ile vurgulandığı söylenebilir.

Tablo 1: Proje Çalışma Ortamının Gözlem Kodlarının Frekanslarını Gösteren Veriler

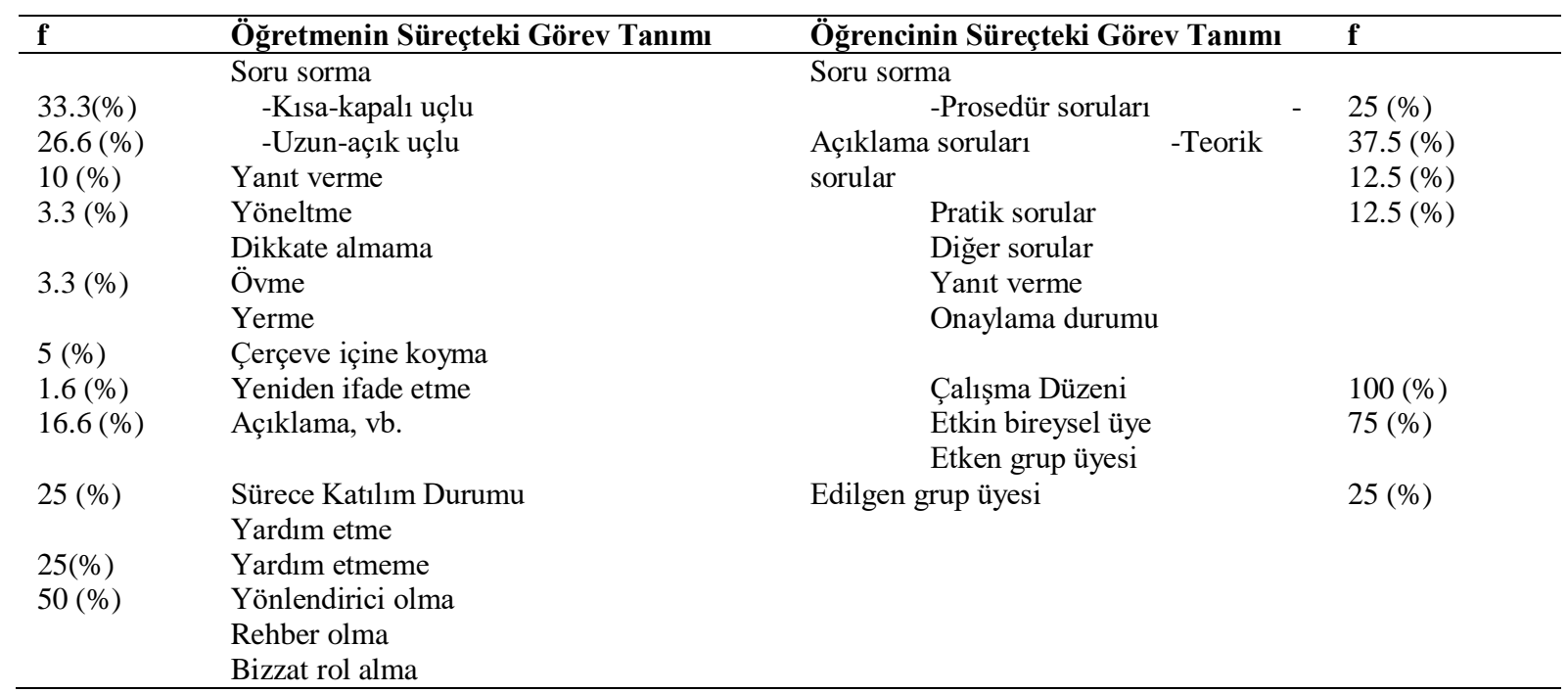

\section{TARTIŞMA VE SONUÇ}

Araştırmanın bulguları değerlendirilerek sonuçlar ortaya konulmuştur. Buna göre, çalışmaya katılan öğrencilerin tamamı ders dışı proje çalışmalarına Fen ve Teknoloji dersi kapsamında katılmış olup, proje çalışmalarına katılan öğrencilerin yaşlarının birbirine yakın olduğu tespit edilmiştir.

Hazırlanan projelerden 3'ü "Elektrik" ünitesi ile ilgili biri ise "Isı ve Işık Enerjisi" ünitesi kapsamındadır ve toplam 4 proje hazırlanmıștır. 
Öğrencilerin tamamı dinlendiğinde öğrencilerin verdikleri bilgilerin doğruluğu teyit edilmiştir. Yapılan gözlemler incelendiğinde, öğretmenin öğrencilere projenin genel amaçlarından bahsettiği, proje çalışmalarını ne için yaptıklarını belirttiği görülmüştür.

Proje çalışmalarının temel amacı için, öğrenciler farklı yaklaşımlar ortaya koymuşlardır. Öğrencilerin verdikleri yanıtlara göre bu projelerden beklentileri farklılaşmaktadır.

Proje çalışmalarına katılan öğrenciler, çalışmalar ile ilgili yöntemler konusunda, "etkili iletişim, sevinçli olarak derse gelme, güdülenme, yardımlaşma, etkin öğrenme, eğlenerek dersi işleme, derse katılım" gibi cevaplar vermişlerdir. Sülün ve ark. (2009), yaptıkları araştırmada, proje çalışmalarına katılan öğrencilerin Fen ve Teknoloji dersini daha çok sevdiklerini ve uygun öğrenme ortamları hazırlandığında öğrencilerin dersi daha aktif, etkili ve kalıcı öğrenebileceklerini tespit etmişlerdir. Öğrencilerin verdikleri cevaplar genel olarak incelendiğinde proje çalışmalarında kullanılan yöntemlerin öğrenciler tarafından olumsuz yanlarına ilişkin bir ifade kullanmadıkları görülmektedir. Çeliker (2012), yaptığı çalışmada, öğrencilerin proje tabanlı öğrenme yöntemine ilişkin olumlu görüşlere sahip olduklarını belirtmiştir. Bunun yanında öğrencilerin, Fen ve Teknoloji derslerinin daha eğlenceli ve zevkli geçtiğini ortaya koymuștur.

Yapılan gözlemler sonucunda da, kullanılan materyallerin karmaşık olmayan ürünler oldukları tespit edilmiştir. Öğrenciler ile yapılan görüşmeler sonucunda, kullandıkları materyallerin; "kolay bulunan, basit yapıll, pratik özelliği olan materyaller olduklarını belirtmişlerdir. Öğrenciler, kendilerinin çalışmaları için karmaşık materyallere ihtiyaçları olmadıklarını belirtmişlerdir. Görüşme yapılan öğrencilerden Ö2, projeleri için günlük hayatlarında çevrelerinden kolaylıkla edindikleri materyalleri seçtiklerini, bunun yanında daha ellerinde daha nitelikli ve kaliteli materyaller olduğunda daha iyi projeler üretebileceklerini ifade etmiştir. MEB, okullarda yürütülen proje çalışmalarına merkezi bütçesinden kaynak ayırmamaktadır. İnisiyatifleri okulların aile birliklerine bırakmaktadır. Sosyo-ekonomik açıdan aşağı düzeyde bulunan okulların proje çalışmalarını materyal sağlama açısından gerekli olan maddi desteği öğrencilere sunması çok olanaklı görünmemektedir.

Öğrencilerin tamamı proje çalışmalarından sonra öğrendikleri yeni bilgileri kullanma konusunda farklı düşünceler ortaya koymuşlardır. Öğrencilerden Ö2, proje çalışması süresince edindiklerini yeni bilgileri kullanarak sınavlarında faydalandığını belirtmiş̧tir. Bunun yanında etkinlik yaparken zorlanmadığını ve daha istekli olduğunu belirtmiştir. Ö7 kodlu öğrenci proje çalışması sonucunda arkadaşları ile iletişim kurmakta daha rahat olduğunu ve iletişim kurarken özgüveninin arttığını belirtmiştir. Ö6 kodlu öğrencide günlük hayatta karşılaştığı bir problemi çözerken daha kolay çözüm üretebildiğini belirtmiştir. Buna göre proje çalışmalarına katılan öğrencilerin görüşlerinin tamamına dikkate alındığında yapılan proje çalışmasının Fen ve Teknoloji Dersi Öğretim Müfredatında belirlenen vizyon ile paralellik taşıdığı görülmektedir. Ayrıca Fen okuryazarı bireylerin yetiştirilmesinde çok önemli olarak görülen "araştıran, sorgulayan, merak eden, eleştirel düşünebilen" gibi özelliklerin çalışmaya katılan öğrenciler tarafından belirtilmesi araștırmanın pozitif etkiye sahip olduğunu göstermektedir.

Gözlemler analiz edildiğinde, öğrencilerin proje çalışmaları sırasında, birbirleri ile iletişim kurarak projeleri hakkında fikirler ve bilgiler edindikleri görülmektedir. Öğrenciler ile yapılan görüşmeler sonucunda; öğrencilerin edinmiş oldukları becerileri, Fen ve Teknoloji ders sınavlarında, ders içi etkinliklerde, doğal hayatlarında rahatça kullanabildiklerini belirtmişlerdir. Thomas (2000), yaptığı araştırmada, PTÖ’nün öğrencilere karmaşık öğrenme süreçlerini öğretmede, problem çözme, iletişim ve karar vermede etkili bir yöntem olduğunu belirtmiştir. Yavuz (2006) yaptığı araştırmada, öğrencilerin grup içinde çalışma yetenekleri kazandıklarını ve daha fazla sorumluluk aldıklarını belirlemiştir. Çıbık ve Emrahoğlu (2008), yaptıkları araştırmada proje tabanlı öğrenme yaklaşımı ile planlanmış ve uygulanmış fen bilgisi derslerinin, klasik öğretim yöntemi ile işlenen fen bilgisi derslerine göre daha etkili olduğu sonucuna ulaşmışlardır. Yapılan proje çalışmaları sonucunda, öğrencilerin tamamına yakının ders başarılarının yükseldiği tespit edilmiştir. Öğrencilerin Fen ve Teknoloji ders içi değerlendirme puanlarında artış olduğu, başarılarının diğer derslere de yansıdığını belirtmişlerdir. Güven (2009), yaptığı araştırmada proje çalışmalarına katılan deney grubu öğrencilerinin akademik başarılarının, kontrol grubu öğrencilerinden anlamlı olarak farklılaştığı sonucuna ulaşmıştır. Özbek (2010) yaptığı 
araştırmada proje tabanlı öğrenme yaklaşımına göre eğitim alan öğrencilerin ön test-son test puanları arasında anlamlı farkın oluştuğunu ortaya koymuştur. Demir (2008) ve Dilşeker (2008), yaptıkları araștırmalarda, proje tabanlı öğrenme yaklaşımına göre ders işlenen deney grubu öğrencilerinin ders başarılarının geleneksel yaklaşıma göre ders uygulanan kontrol grubu öğrencilerine göre istatistiki açıdan anlamlı olduğunu ortaya koymuştur. Buna göre proje tabanlı öğrenme yaklaşımına göre ders işlenen deney grubu öğrencilerinin ders başarılarının daha yüksek çıktığı söylenebilir. Çakallıoğlu (2008), yedinci sınıflar ile yaptığı araştırmasında "Ya Basınç Olmasaydı?" isimli ünitede proje çalışmaları ile işlenen deney grubu öğrencilerinin ders başarılarının ve derse karşı tutumlarının, geleneksel öğrenme yöntemleri ile işlenen kontrol grubu öğrencilerinden daha fazla olduğunu belirlemiştir. Keskin (2011), yaptığı çalışmada, proje tabanlı öğrenme yöntemi ile ders işlenen deney grubu öğrencileri ile müfredata göre ders işlenen kontrol grubu öğrencilerinin ders başarıları arasında deney grubunun lehine yönelik anlamlı bir fark bulmuştur. Özahioğlu (2012), yaptığı araştırmada, proje tabanlı öğrenmenin öğrencilerin bilimsel süreç becerilerine, derse yönelik tutumlarına ve ders başarılarına olumlu katkılar getirdiğini ortaya koymuştur.

Öğrenciler ile yapılan görüşmeler sonucunda, proje çalıșmaları sürecinde edinmiș oldukları kazanımları diğer disiplinlere bașarılı bir șekilde yansıttıkları, hayatlarının okul dıșındaki bölümlerinde çalışmalarda kazanmış oldukları bilimsel tutumları burada da sergilediklerini belirtmişlerdir. Proje çalışmalarına katılan öğrencilerden Ö1 kodlu öğrenci hariç, geriye kalan öğrencilerin tümü ( $\mathrm{n}=4)$, Fen ve Teknoloji ders içi ve ders dışı ve diğer derslerdeki, akademik ders başarılarının arttığını ifade etmişlerdir. Bu araştırmada elde edilen bu sonuca benzer çalışmalar mevcuttur. Solomon (2003), öğrencilerin proje tabanlı öğrenme yaklaşımı ile gerçek dünya problemleri ile yüzleştiklerini ve bunları çözmek için çaba gösterdiklerini ve sürece motive olduklarını belirtmiştir.

Süreç boyunca öğrencilerin ve öğretmenlerin rolleri çeşitli kategoriler altında incelenmiştir. Öğretmenlerin süreç boyunca büyük oranda öğrencilerine rehberlik ettiği, öğrencilerin başarılı olduklarını onlara hissettirmek için onların verdikleri yanıtları övdüğü (\%3.3), doğru biçimde devam ettirebilmeleri için kısa-kapalı uçlu (\%33.3) sorular yönelttiği belirlenmiştir. PTÖ’nün genel yapısı düşünüldüğünde yapılan gözlemler öğretmenin süreç boyunca doğru bir șekilde davrandığını göstermektedir. Öğrencilerin süreçteki rolleri ise yapılan gözlemlerden sonra, sordukları soruların türleri, yanıt verme biçimleri ve çalışma düzenleri olarak belirlenmiştir. Proje çalışmaları süresince öğrencilerin teorik soru sorma oranları düşük seviyede (\%12.5) olmuştur. Öğrencilerin sordukları soruların önemli bölümü (\%37.5) prosedür soruları kategorisi altında toplanmıştır. Öğrencilerin tamamına yakınının süreç boyunca öğretmenlerinin yönelttiği sorulara doğru yanıtlar vermesi ve projelerin çalışarak işlevlerini yerine getirmesi çalışma sürecinden verim alındığını ortaya koymaktadır. Öğrencilerin proje çalışma sürecinin tamamında çalışma düzeninin uygun olduğu ve öğrencilerin süreçte uymaları gerekli kurallara öğretmenleri herhangi bir uyarı yapmadan uydukları yapılan gözlemler sonucunda belirlenmiștir. Bu gözlem sonucu, dersin öğretim programında belirtilen ve öğrencilerin kazanması gereken kazanımların PTÖ kapsamında gerçekleştirilen bu tür çalışmalar ile kazanılabileceğini göstermektedir.

\section{Öneriler}

Proje çalışmalarına katılan öğrencilerin yapmıș oldukları çalışmaların çoğunlukla aynı ünite kapsamında oluşturulduğu görülmektedir. Öğrencilerin diğer disiplinler ile başarılı bir şekilde bütünleşmelerini sağlamak için farklı ünitelerden de konular seçilerek projeler hazırlanması önerilebilir.

Sürdürülmekte olan bu çalışmaların daha verimli olabilmesi açısından öğrencilerin kullandığı materyallerin geliştirilerek projeleri için kullanmaları projelerin görsel ve içerik bakımından zenginleştirilmesi sağlanabilir.

Öğrencilerin genel olarak basit yapılı materyaller kullandıkları görülmüştür. Dolayısı ile daha başarılı projelerin, daha karmaşık ve daha özgün projelerin ortaya çıkarılması için farklı materyallerin kullanılması önerilebilir. Bu kapsamda okul idarelerinin ve okul aile birliklerinin proje çalışmalarına katılan öğrencileri desteklemeleri önerilebilir. Ekonomik açıdan öğrencilerini destekleyecek kaynakları bulunmayan okullara MEB tarafından özellikle ya materyal desteği ya 
da maddi kaynak ayırılmasının sağlanması gereklidir. Böylelikle proje çalışmalarına katılan öğrencilerin yaratıcılıklarını daha fazla ön plana çıkarabilecekleri söylenebilir.

Proje çalışmaları sonucunda, proje çalışmalarında yer alan öğrencilerin Fen ve Teknoloji ders başarılarında bir artış olduğu göz önünde bulundurulduğunda bu çalışmalara daha fazla öğrencinin etkin biçimde katılması sağlanabilir. Bunun yanında ulusal düzeyde düzenlenen $\mathrm{Bu}$ Benim Eserim Proje yarışmasında ve ülkemizdeki bilimsel eğitim kurumları tarafından düzenlenen ulusal yarışmalarda ülke genelinde dereceye giren öğrencilerin özellikle TEOG sınav puanlarına ek olarak puan verilmesi sağlanabilir. Bu uygulama ile ülke genelinde daha fazla öğrencinin Fen ve Teknoloji dersi kapsamındaki proje çalışmalarına gönüllü olarak yönelmesi sağlanabilir.

Proje çalıșmalarının öğrencilerin fen ve teknoloji okuryazarı bireyler olarak yetişmelerine pozitif yönde etki yapıldığı göz önüne alındığında PTÖ'nün Fen Bilimleri/Fen ve Teknoloji derslerinde süreç boyunca etkin biçimde kullanılması önerilebilir.

Not. Bu çalışma, International Conference on Education in Mathematics, Science \& Technology (ICEMST 2014) kapsamında sözlü bildiri olarak sunulmuștur.

\section{KAYNAKÇA}

Akcay, B. \& Akcay H. (2015). Effectiveness of science-technology-society (STS) instruction on student understanding of the nature of science and attitudes toward science. International Journal of Education in Mathematics, Science and Technology, 3(1), 37-45.

Akdeniz, A. R. (2007). Kuramdan Uygulamaya Fen ve Teknoloji Öğretimi (Edt. Salih Çepni). Problem Çözme, Bilimsel Süreç ve Proje Yönteminin Fen Eğitiminde Kullanımı (4. Ünite). Ankara: Pegama Yayıncllık.

Aktepe, V. \& Aktepe, L. (2009). Fen ve Teknoloji Öğretiminde Kullanılan Öğretim Yöntemlerine İlişkin Öğrenci Görüşleri: Kırşehir BİLSEM Örneği. Ahi Evran Üniversitesi Kırşehir Eğitim Fakültesi Dergisi (KEFAD), 10 (1), 69-80.

Aydın, M. (2011). Fen ve Teknoloji Öğretmenleri İçin Geliștirilen Proje Tabanlı Öğretim Yöntemi Konulu Bir Destek Programının Etkilerinin Araştırılması. Doktora Tezi, Trabzon: Karadeniz Teknik Üniversitesi, Eğitim Bilimleri Enstitüsü.

Çakallığlu, S. N. (2008). Proje Tabanlı Öğrenme Yaklaşımına Dayalı Fen Bilgisi Öğretiminin Akademik Başarı ve Tutuma Etkisi. Yüksek Lisans Tezi. Adana: Çukurova Üniversitesi, Sosyal Bilimler Enstitüsü.

Colley, K., E., 2008. Project-Based Science Instruction: A Primer, An Introduction and Learning Cycle for Implementing Project-Based Science, The Science Teacher, November, 23-28.

Çeliker, D. H., (2012). Fen ve Teknoloji Dersi “Güneş Sistemi ve Ötesi?: Uzay Bilmecesi” Ünitesinde Proje Tabanlı Öğrenme Uygulamalarının Öğrenci Başarılarına, Yaratıcı Düşünmelerine, Fen ve Teknolojiye Yönelik Tutumlarına Etkisi. Yayımlanmamıș Doktora Tezi, Dokuz Eylül Üniversitesi, İzmir.

Çıbık, A.S. \& Emrahoğlu, N. (2008). Proje Tabanlı Öğrenme Yaklaşımının Fen Bilgisi Dersinde Öğrencilerin Mantıksal Düşünme Becerilerinin Gelişimine Etkisi. Ç.Ü. Sosyal Bilimler Enstitüsü Dergisi, 17(2), 5166.

Demir, K. (2008). Bütünleştirilmiş Öğretim Programının İşbirliğine Dayalı ve Proje Tabanlı Öğrenme Yaklaşımıyla Uygulanmasının Etkililiği. Doktora Tezi, Hacettepe Üniversitesi Sosyal Bilimler Enstitüsü, Ankara.

Dilşeker, Z. (2008). Fen ve Teknoloji Dersinde Proje Tabanlı Öğrenme Yönteminin Kullanımının İlköğretim 5. Sınıf Öğrencilerinin Fen ve Teknoloji Dersine Yönelik Tutumlarına, Ders Başarılarına ve Kavram Yanılglarının Giderilmesine Etkisi. Yüksek Lisans Tezi, Dokuz Eylül Üniversitesi, İzmir.

Erdem, M. (2002). Proje Tabanlı Öğrenme. Hacettepe Üniversitesi, Eğitim Fakültesi Dergisi, 22, 172-179.

Erdem, M. ve Akkoyunlu, B. (2002). İlköğretim Sosyal Bilgiler Dersi Kapsamında Beşinci Sınıf Öğrencileriyle Yürütülen Ekiple Proje Tabanlı Öğrenme Üzerine Bir Çalışma, İlköğretim-Online1,1, 2-11.

Girgin, A. (2003). Proje Temelli Öğrenme Yönteminin Özel Konya Esentepe İlköğretim Okulu Tarafından Uygulanmasına Yönelik Bir Değerlendirme. Yayımlanmamış Yüksek Lisans Tezi, Selçuk Üniversitesi, Konya.

Güven, İ. (2009). Fen ve Teknoloji Öğretmen Adaylarının Proje Yönetimi Deneyimlerinin Değerlendirilmesi. Hacettepe Üniversitesi Eğitim Fakültesi Dergisi (H. U. Journal of Education) Özel Sayı (1), 204-218 [2013].

Katz, G.L., and Chard, C. S. (2000). Engaging Children's Minds: The Project Approach, 215p. 
Keskin, E. (2011). Proje Tabanlı Öğrenme Yönteminin İlköğretim İkinci Kademe Öğrencilerinin Başarı ve Fen Motivasyonlarına Etkisinin İncelenmes. Yayımlanmamış Yüksek Lisans Tezi, Uludağ Üniversitesi, Bursa.

Korkmaz, H. ve Kaptan, F. (2002). Fen Eğitiminde Proje Tabanlı Öğrenme Yaklaşımının İlköğretim Öğrencilerinin Akademik Başarı, Akademik Benlik Kavramı ve Çalışma Sürelerine Etkisi. Hacettepe Üniversitesi Eğitim Fakültesi Dergisi. 22: 91-97.

MEB., (2005). İlköğretim Fen Ve Teknoloji Dersi Öğretim Programı. Ankara: Milli Eğitim Basımevi.

MEB., (2015). İlköğretim Kurumları Fen Bilimleri Dersi Öğretim Programı. Ankara. Milli Eğitim Basımevi.

Miles, M. B., \& Huberman, A. M. (1994). Qualitative data analysis: An expanded sourcebook (2nd ed.). Thousand Oaks, California: Sage Publications.Miller, D. (2001). Principles of Social Justice. Harvard University Press. [Çevrim-içi:http://www.hup.harvard.edu/catalog.php?isbn=9780674007147], Erișim tarihi: 16.04 .2014 .

Özahioğlu, B., (2012). İlköğretim Fen ve Teknoloji Dersinde Proje Tabanlı Öğrenmenin Bilimsel Süreç Becerilerine, Başarı ve Tutum Üzerine Etkisi. Yayımlanmamış Yüksek Lisans Tezi, Çanakkale On Sekiz Mart Üniversitesi, Çanakkale.

Özbek, Ö. (2010). İlköğretim Fen ve Teknoloji Dersinde Küresel Isınma Konusunun Proje Tabanlı Öğretim Modelinde İncelenmesi. Yüksek Lisans Tezi, İnönü Üniversitesi, Eğitim Bilimleri Enstitüsü, Malatya.

Patton, M. Q. (1987). How to use qualitative methods in evoulation. Newbory Park, CA: Sage.

Saban, A. (2002). Öğrenme Öğretme Süreci Yeni Teori ve Yaklaşımlar. Ankara: Nobel Yayın Dağıtım.

Solomon, G. (2003). Project-Based Learning: A Primer. [Çevrim-içi:
[Crişim http://pennstate.swsd.wikispaces.net/file/view/PBL-Primer-www_techlearning_com.pdf], Erişim tarihi: 20.03.2016.

Sülün, Y., Ekiz S.O ve Sülün, A. (2009). Proje Yarıșmasının Öğrencilerin Fen ve Teknoloji Dersine Olan Tutumlarına Etkisi ve Öğretmen Görüşleri, Erzincan Eğitim Fakültesi Dergisi, 11-1.

URL 1: www.meb.earged.gov.tr. 15.01.2011 tarihinde indirilmiştir.

Thomas, W. J. (2000). A Review of Research On Project-Based Learning. [Çevrim-içi: http://www.newtechnetwork.org.590elmp01.blackmesh.com/sites/default/files/dr/pblresearch2. pdf], Erișim tarihi: 22.03.2016.

URL 2: http://tegm.meb.gov.tr/bubenimeserim/kilavuz.pdf. 10.02.2014 tarihinde indirilmiştir.

Yavuz, S. (2006). Proje Tabanlı Öğrenme Modelinin Kimya Eğitimi Öğrencilerinin Çevre Bilgisi İle Çevreye Karşı Tutumlarına Olan Etkisinin Değerlendirilmesi. Yayımlanmamış Doktora Tezi, Hacettepe Üniversitesi Fen Bilimleri Enstitüsü, Ankara.

Yıldırım, A. ve Şimşek, H. (2011). Sosyal Bilimlerde Nitel Araştırma Yöntemleri. Ankara: Seçkin Yayıncılık.

Yurtluk, M. (2003). Proje Tabanlı Öğrenme Yaklaşımının Matematik Dersi Öğrenme Süreci Ve Öğrenci Tutumlarına Etkisi. Yayımlanmamış Yüksek Lisans Tezi, Hacettepe Üniversitesi Sosyal Bilimler Enstitüsü, Ankara.

Yurttepe, S. (2007). İlköğretim Fen Bilgisi Dersinde Proje Tabanlı Öğrenmenin Öğrenci Başarısına Etkisi. Yayımlanmamış Yüksek Lisans Tezi, Osmangazi Üniversitesi Fen Bilimleri Enstitüsü, Eskişehir.

Zorbaz, K., Z. ve Çeçen, M., A., (2009). Proje Tabanlı Öğretim ve Türkçe Öğretiminde Kullanımı, Ankara Üniversitesi Eğitim Bilimleri Fakültesi Dergisi, 42, 1, 87-104. 